\title{
FITNESS OF HYBRIDS BETWEEN WEEDY AND CULTIVATED RADISH: IMPLICATIONS FOR WEED EVOLUTION
}

\author{
Allison A. Snow, Kristen L. Uthus, and Theresa M. Culley \\ Department of Evolution, Ecology, and Organismal Biology, Ohio State University, Columbus, Ohio 43210-1293 USA, and \\ University of Michigan Biological Station, Pellston, Michigan 49569 USA
}

\begin{abstract}
Weed species are known to evolve rapidly with their associated crops. A better understanding of the mechanisms and rates of weed evolution could aid in limiting or at least anticipating this process. Spontaneous hybridization between crops and related weed species can transfer crop genes coding for fitness-enhancing traits to wild populations, but little is known about how easily this takes place in various weed-crop complexes. We studied interspecific hybrids between wild and cultivated radishes (Raphanus raphanistrum $\times R$. sativus), which often co-occur and share pollinators. To determine whether the $F_{1}$ generation represents a strong barrier to subsequent introgression, we compared the fitness of wild plants and wild-crop hybrids. Two experiments were carried out in Michigan, USA, one with potted plants and the other involving four artificially established populations. In the artificial populations, we used white flower color, a dominant, crop-specific allele, to document the persistence of crop genes over time. Wild plants had yellow flowers, which is a recessive trait. $F_{1}$ hybrids had lower fitness than wild plants due to lower pollen fertility, fewer seeds per plant, and delayed flowering. Despite these disadvantages, hybrids contributed substantially to each population's gene pool. After $3 \mathrm{yr}$, frequencies of whiteflowered plants in the artificial populations ranged from $8 \%$ to $22 \%$, demonstrating that crop genes persisted. Other studies of flower color variation in wild populations of $R$. raphanistrum provide circumstantial evidence for frequent crop-to-wild gene flow. We predict that, if cultivated radish is engineered to possess transgenes coding for traits such as resistance to insect herbivores, disease, herbicides, or environmental stress, these fitnessrelated crop genes will easily spread to $R$. raphanistrum.
\end{abstract}

Key words: adaptation; artificial populations; crop; fitness-related trait; flower color; hybridization; introgression; pollen fertility; Raphanus raphanistrum; transgenic; weed; wild radish.

\section{INTRODUCTION}

Many crops hybridize spontaneously with related weeds, including rice, sunflower, sorghum, squash, canola, radish, and carrot (Ellstrand and Hoffman 1990, Snow and Morán Palma 1997). However, little is known about the extent to which crop-to-wild gene flow fosters adaptive evolution in weeds. One reason little attention has been paid to this question is that useful agronomic traits have often been obtained from wild relatives in the first place, creating the impression that weeds are already very well adapted to local conditions. In addition, certain crop traits such as a short flowering period or lack of seed dormancy would likely be detrimental to wild plants, leading to the conclusion that most crop genes would have deleterious or neutral effects on the fitness of wild or weedy relatives (National Research Council 1989). In some cases, however, agricultural breeding has resulted in crops with singlegene resistance traits that are easily transferred to wild populations lacking these traits. For example, resistance to a fungal disease (Puccinia spp.) has been bred into cultivated sunflowers (Helianthus annuus) using wild germplasm (Seiler 1992). This trait is not ubiq-

Manuscript received 17 September 1999; revised 1 April 2000; accepted 3 April 2000. uitous in wild/weedy sunflower populations (also $H$. anпииs) and can spread to wild populations via cropto-wild gene flow (Snow et al. [1998] and references therein).

With the recent commercialization of transgenic crops, it is likely that many more single-gene traits will be available for crop improvement and, inadvertently, the "improvement" of associated weedy relatives. Crops with transgenic resistance to viral diseases, insect pests, and herbicides are already being grown commercially, and it is inevitable that these and other fitness-related traits will make their way into wild populations via the dispersal of transgenic pollen and seeds. Concern about the ecological and evolutionary effects of these types of transgenes has been raised repeatedly (e.g., Colwell et al. 1985, Tiedje et al. 1989, Ellstrand and Hoffman 1990, Raybould and Gray 1993, Rissler and Mellon 1996, Snow and Morán Palma 1997), prompting a closer look at the ease with which crop genes spread to wild populations in various cropwild complexes. Studies of radish, squash, and sunflower, for example, showed that pollinators were capable of transporting crop pollen to related weeds over distances as great as $1 \mathrm{~km}$ (Kirkpatrick and Wilson 1988, Klinger et al. 1991, 1992, Arias and Rieseberg 1994). Spontaneous hybridization can occur even when 
the crop and the weed have different chromosome numbers or represent different genera, as in Brassica napus $\times$ B. rapa, Sorghum bicolor $\times S$. halapense, and Triticum aestivum $\times$ Aegilops cylindrica (Jørgensen and Andersen 1994, Arriola and Ellstrand 1996, Zemetra et al. 1998). Once it is known that this process takes place in a given crop-weed system, it is important to confirm that crop genes actually persist in weedy populations (e.g., Chevre et al. 1997, Whitton et al. 1997, Linder et al. 1998). If this is the case, we also need to assess the impact of fitness-related crop genes on the fitness, abundance, and geographic distribution of wild and/or weedy relatives.

The purpose of this study was to examine the extent to which genes from cultivated radish (Raphanus sativus) can persist in populations of $R$. raphanistrum, which is a major agricultural weed in Eurasia, North America, and Australia (e.g., Thomas et al. 1984, Cheam and Code 1995, Holm et al. 1997, Fischer et al. 1999). We hypothesized that $F_{1}$ hybrids would have lower fitness than wild genotypes, but that crop-specific markers that are not linked to deleterious traits would persist in subsequent generations. One phase of our research involved comparing the reproductive success of $F_{1}$ hybrids with that of purely wild plants when the plants were grown outdoors in pots. A second approach was to establish isolated, artificial populations of wild and hybrid plants in which genetic markers could be used to track the long-term persistence of crop genes. While the potted plants were convenient for quantifying the reproductive success of the two cross types under uniform conditions, the experimental populations had the advantage of allowing ecological factors such as competition, herbivory, drought stress, flowering phenology, seed predation, and overwintering conditions to influence the persistence of crop genes from one generation to the next. These populations will also permit us to determine the rate at which deleterious traits such as low pollen fertility are purged over time due to natural selection. Here we report results from the potted-plant experiment, the first generation of the field experiment, and persistence of a flower-color marker in the field $3 \mathrm{yr}$ later. Year-to-year changes in allozyme markers, flower color frequencies, and pollen fertility will be described further in a subsequent paper (Uthus, Snow, and Culley, unpublished manuscript).

\section{Methods}

\section{The study system}

Cultivated radish (Raphanus sativus) is composed of many varieties that have a swollen edible root, a spongy fruit capsule that crushes easily by hand, and white, pink, or purple petals (but not yellow) with a variety of vein colors (Panetsos and Baker 1967; Table 1). In California, $R$. sativus has escaped from cultivation and colonizes disturbed sites such as roadsides, fields, and coastal sand dunes (Panetsos and Baker 1967; A. A.
TABLE 1. Flower color morphs of cultivated Raphanus sativus, feral $R$. sativus, and $R$. raphanistrum in the United States (from Kercher and Conner 1996, Stanton 1987).

\begin{tabular}{|c|c|c|c|c|}
\hline Plant type & Yellow & White & Pink & $\begin{array}{l}\text { Bronze } \\
\text { (yellow } \\
+ \text { pink) }\end{array}$ \\
\hline Cultivated Raphanus sativus & & $\mathrm{XX}$ & $\mathrm{XX}$ & \\
\hline Feral Raphanus sativus & XX & $\mathrm{XX}$ & $\mathrm{XX}$ & $\mathrm{X}$ \\
\hline Raphanus raphanistrum & XX & $\mathrm{X}$ & $\mathrm{X}$ & $\mathrm{X}$ \\
\hline
\end{tabular}

Note: Common color morphs are indicated by $\mathrm{XX}$, and rare morphs are designated by $\mathrm{X}$ (frequencies vary among populations).

Snow, personal observation). This type of wild radish has been the subject of many investigations of pollination ecology and gene flow, including research on the fitness of $F_{1}$ hybrids between wild and cultivated R. sativus (Klinger and Ellstrand [1994] and references therein). Raphanus raphanistrum, which is also known as wild radish or jointed charlock, has never been domesticated and occurs in agricultural fields and along sheltered beaches (Holm et al. 1997; A. A. Snow, personal observation). In the USA, natural populations of $R$. raphanistrum mainly occur in the midwest and eastern states, where feral $R$. sativus is rare or absent (Kercher and Conner 1996; A. A. Snow, personal observation). Raphanus raphanistrum also occurs in $>65$ countries on several continents and is ranked as one of the 100 most economically damaging weeds worldwide (Holm et al. 1997).

Raphanus raphanistrum is morphologically similar to wild $R$. sativus and both differ from cultivated $R$. sativus by forming a deep, branching taproot during the rosette stage, and by flowering more quickly than cultivated radish (both species are annuals in temperate climates; Panetsos and Baker 1967). The seeds of $R$. raphanistrum are encased in a woody, segmented fruit capsule (silique) that often has square-edged constrictions between the seeds. Fruit segments eventually break apart and seeds can then be dispersed individually. The seeds germinate readily when the woody fruit segment around each seed becomes cracked and conditions are favorable for germination. In the absence of germination cues, the seeds can remain viable in the soil for many years (Holm et al. 1997).

These two wild radish species, $R$. raphanistrum and feral $R$. sativus, differ in flower color frequencies (Table 1). Most populations of $R$. raphanistrum consist of yellow-flowered plants, occasionally intermixed with white or, more rarely, pink or bronze morphs (bronze is a blend of pink and yellow). In contrast, white, pink, and yellow-flowered plants are all common in feral populations of $R$. sativus. Because yellow flowers are not seen in cultivated radish, it is likely that feral $R$. sativus has hybridized with $R$. raphanistrum (Panetsos and Baker 1967, Stanton 1987, Kercher and Conner 1996; see Discussion). Both types of wild radish are pollinated by a variety of insects including bumble 
bees, halictid bees, syrphid flies, honey bees, and butterflies (e.g., Stanton 1987, Conner and Rush 1996, Lee and Snow 1998). Cabbage butterflies (Pieris rapae) show a strong preference for yellow-flowered plants over white (Kay 1976, Stanton et al. 1986, Lee and Snow 1998), but many other common flower visitors do not (Kay 1976, Stanton 1987, Lee and Snow 1998).

Interspecific hybrids between Raphanus raphanistrum and $R$. sativus are vigorous and fertile (both species have $2 n=18$ chromosomes), although $F_{1}$ hybrids typically have about $50-60 \%$ aborted pollen grains ( $\mathrm{Pa}-$ netsos and Baker 1967). Low pollen fertility is due to the fact that hybrids are heterozygous for a reciprocal translocation that affects chromosome pairing during meiosis (Panetsos and Baker [1967] and references therein). Raphanus raphanistrum is likely to hybridize with cultivated radishes in areas where the crop is grown for its seed or in fields where it is neglected and eventually bolts (and flowers; A. A. Snow, personal observation).

\section{Potted plant experiment}

The goal of this experiment was to compare the lifetime fecundity of wild and wild-crop hybrids when grown outdoors under uniform conditions. $F_{1}$ hybrids were obtained by crossing 18 yellow-flowered wild plants from Bay City, Michigan, with 12 Scarlet Globe $R$. sativus plants, all of which had white or pink flowers, in a pollinator-free greenhouse in 1996. Scarlet Globe is a common garden variety that is grown in many areas of the USA. To mimic crop-to-wild gene flow, wild plants were used as pollen recipients. Emasculation was not necessary because $R$. raphanistrum is self-incompatible (Sampson 1964). Several flowers on each wild plant received pollen from another wild individual, and an equal number of flowers received pollen from $R$. sativus, which was homozygous for the white petal allele. Seed set from both pollen sources was very high (A. A. Snow, personal observation). Nevertheless, we did not have enough seeds to test for possible differences in seed dormancy or survival under natural winter conditions, so this phase of the plants' life cycle was necessarily omitted from fitness comparisons. Seeds were placed in starter cells under a greenhouse mister on May 1996. The seeds germinated synchronously within 4-6 d, and differences between cross types in percentage germination or time to emergence were not significant (data not shown). Seedlings were transplanted to pots one week later, for a total of 40 potted plants from each cross type (one plant per pot). All parental plants were represented by $1-4$ progeny.

Plants were grown outdoors in pots at the University of Michigan Biological Station in northern lower Michigan (Pellston, Emmet County, 42 $35^{\prime} \mathrm{N}, 84^{\circ} 42^{\prime} \mathrm{W}$ ). The pots were $2.5 \mathrm{~L}$ in volume, with mesh bottoms. The bottom half of each pot was filled with local sand, topped with $1 \mathrm{~L}$ of standard potting mix (a mixture of peat, vermiculite, organic mulch, and starter nutrients). Pots were placed in a large fenced enclosure where local vegetation had been cleared away to expose the sandy soil beneath. Plants were watered as needed and $3.5 \mathrm{~g}$ of slow-release Osmocote fertilizer $(14 \mathrm{~N}-14 \mathrm{P}-$ $14 \mathrm{~K}$ [Scott's, Marysville, Ohio]) was added to each pot 3 wk after seedling emergence. Every two weeks, pots were haphazardly relocated to equalize possible microsite effects and prevent the plants' roots from penetrating the sandy soil below each pot. About midway through the flowering period, most plants became infested with aphids, which were largely controlled by hand-spraying the plants once or twice with malathion. Local pollinators were abundant (Lee and Snow 1998).

For each plant, we recorded the date flowering began, pollen fertility, ovules per flower, seeds per fruit, and the total numbers of flowers and fruits. Pollen fertility was assessed by collecting pollen from two anthers per plant on a microscope slide, staining the pollen (Alexander 1969), and using a compound microscope to count the proportion of aborted grains in samples of $\geq 200$ grains per plant. A few extra hybrid plants were grown to obtain additional data on pollen viability, thereby compensating for hybrids that never flowered. Ovule number was determined from two flowers per plant, and mean seed number per fruit was calculated from 10 fruits per plant (flowers and fruits were chosen haphazardly). Total seed number was estimated by multiplying the number of fruits per plant by the mean number of seeds per fruit.

\section{Experimental field populations}

This experiment also involved comparisons between wild plants and $F_{1}$ hybrids, but in this case the wild parents came from a population at Ocean Point, Maine, USA, and their progeny were grown in field populations. The source population in Maine was fixed for the yellow flower morph (A. A. Snow, personal observation). Wild plants were selected for crosses based on specific alleles of GPI (glucophosphoisomerase) and PGM (phosphoglucomutase) that were distinct from alleles found in the Scarlet Globe plants we used (electrophoretic methods as in Conner et al. [1997]). These two loci are not linked and therefore represent independent genetic markers (Conner et al. 1997). Seeds from our Michigan collection could not be used for this experiment because the GPI and PGM alleles that were rare in the crop were not sufficiently common in Michigan. We assumed that switching to wild genotypes from Maine would not affect the outcome of the experiment, in part because patterns of genetic variation within and among populations of $R$. raphanistrum suggest little variation among regions (Kercher and Conner 1996).

In addition to the two allozyme loci, flower color provided a third crop-specific genetic marker. The presence of yellow carotenoid pigment is a recessive Mendelian trait, with white dominant over yellow (Kay 
TABLE 2. Characteristics of the four experimental populations in Michigan and frequencies of a dominant, crop-specific Raphanus flower color marker (white petals) in 1998 and 1999. In the first year (1996), each population consisted of 100 wild plants and $100 F_{1}$ hybrids.

\begin{tabular}{|c|c|c|c|c|c|c|c|}
\hline \multirow[b]{2}{*}{ Site name } & \multirow{2}{*}{$\begin{array}{l}\text { Local } \\
\text { vegetation }\end{array}$} & \multirow{2}{*}{$\begin{array}{l}\text { Relative size of } \\
\text { plants in } 1996\end{array}$} & \multicolumn{3}{|c|}{$\begin{array}{l}\text { Estimated size of population } \\
\text { (number of flowering plants) }\end{array}$} & \multicolumn{2}{|c|}{$\begin{array}{c}\text { Proportion with dominant } \\
\text { crop marker§ }\end{array}$} \\
\hline & & & $1997 \dagger$ & $1998 \ddagger$ & 1999 & 1998 & 1999 \\
\hline $\begin{array}{l}\text { Biological Station } \\
\text { (BS) }\end{array}$ & forest & $\begin{array}{l}\text { very large } \\
\quad(>1.0 \mathrm{~m} \text { tall })\end{array}$ & $\sim 2805$ & $\sim 14380$ & $\sim 101000$ & 0.15 (3 177) & $0.15(955)$ \\
\hline Riggsville Road (RR) & forest & large & $\sim 2127$ & $\sim 3770$ & $\sim 86000$ & $0.17(1009)$ & $0.22(1004)$ \\
\hline $\begin{array}{l}\text { Greenstar Meadow } \\
\quad(\mathrm{GM})\end{array}$ & $\begin{array}{l}\text { meadow, } \\
\text { young forest }\end{array}$ & medium small & 303 & 164 & $\sim 3592$ & 0.07 (164) & $0.08(457)$ \\
\hline Pellston Plains (PP) & $\begin{array}{l}\text { grassland, } \\
\text { very dry }\end{array}$ & $\underset{(<0.5 \mathrm{~m} \text { tall })}{\mathrm{small}}$ & 237 & 58 & $\sim 1123$ & $0.07(58)$ & $0.10(361)$ \\
\hline
\end{tabular}

$\dagger$ Only half of the area at each population was rototilled in 1997.

† Seedlings at GM and PP were grown ex situ for 1-2 mo to protect them from insect herbivores. Manure was added to these two sites in September 1998.

$\S$ Number of plants counted for flower color frequencies is shown in parentheses.

1976, 1978, Stanton 1987; the genetic basis of the pink hue is more complex). Both pink and white-flowered plants share the dominant allele for lack of carotenoid pigment. As above, the crop plants used in our crosses were homozygous for the dominant allele, while wild plants were homozygous for the recessive allele, and all $F_{1}$ hybrids produced white or pink flowers. Preliminary studies indicate that flower color is not linked to the reciprocal translocation locus or to genes for delayed flowering in the crop (K. L. Uthus and A. A. Snow, unpublished data).

After identifying wild and crop plants with mutually exclusive isozyme alleles, we made wild $\times$ crop and wild $\times$ wild crosses. Seeds were obtained from 17 wild plants (presumably unrelated) and eight crop pollen donors, which became the founding parents of the artificial populations. The seeds were harvested in late June 1996 and were immediately cracked out of their fruits, planted in biodegradable pots $(8 \times 8 \times 8 \mathrm{~cm})$ filled with potting soil, and placed in a greenhouse to germinate.

Four field populations were established at the University of Michigan Biological Station, at elevations of 212-236 m. The field sites are located on open, unshaded sites that have not been farmed for $\geq 50 \mathrm{yr}$, if at all, so it is unlikely that wild radish seeds were present in the soil (R. Vande Kopple, personal communication). Due to the sandy, infertile soils in this region, $R$. raphanistrum is uncommon and appears to be restricted to fertilized agricultural land (typically land in rotations of potato, corn, and alfalfa; A. A. Snow and K. L. Uthus, personal observation). Therefore, it was possible to create isolated populations that are unlikely to spread beyond limits of their artificially amended soil. The populations were separated by $\geq 2$ $\mathrm{km}$ and were $\sim 5 \mathrm{~km}$ from the nearest naturally occurring $R$. raphanistrum population. We have not seen flowering $R$. sativus within this 5 -km radius, most of which is forested. Characteristics of each of the four sites are listed in Table 2. Abbreviations for the populations are BS (Biological Station), RR (Riggsville
Road), GM (Greenstar Meadow), and PP (Pellston Plains).

Each experimental population was established in the following manner. First, a bulldozer was used to clear off existing vegetation (grass, brush, small trees) and remove the top $\sim 30 \mathrm{~cm}$ of soil and roots from an area $>15 \times 15 \mathrm{~m}$. The excavated area was then filled with local Kalkaska series topsoil, which was rototilled a few days before planting, and a $3 \mathrm{~m}$ high fence was erected around the area to exclude deer. Two-week-old seedlings were planted with their biodegradable pots during the first week of July. This planting date was $\sim 1$ mo later than the time when seedlings of $R$. raphanistrum begin to emerge in Emmet County, but was well within the range of natural germination times in local agricultural fields (A. A. Snow and K. L. Uthus, personal observation).

Each population consisted of 10 rows with 20 plants per row, half of which were $F_{1}$ wild-crop hybrids and half of which were wild. Within rows, ten plants per cross type were randomly assigned to positions that were $60 \mathrm{~cm}$ apart, with $\sim 1.5 \mathrm{~m}$ between rows. We watered the seedlings at the time of planting and the few that died due to transplant shock were immediately replaced with plants of the same cross type. A layer of oat straw $3-5 \mathrm{~cm}$ thick was spread over the remaining bare soil to reduce evaporation and inhibit other weeds. This mulch did not completely inhibit interspecific competition, however, because the straw contained oat seeds that germinated and took hold. Therefore, a 10$\mathrm{cm}$ radius was cleared around each experimental plant to encourage successful establishment. Each plant also received $3.5 \mathrm{~g}$ of slow-release Osmocote fertilizer on 6 July and 22 July. Large invading plants such as bracken fern (Pteridium aquilinum) were spot-treated with herbicide (glyphosate), which was also applied to a buffer zone outside the fenced areas. Any volunteer radishes were removed as seedlings $(\sim 10-15$ individuals were found at each site). These unexpected volunteers probably came from the mulch or the layer of new topsoil rather than from local soils. In any case, 
frequencies of unwanted seeds were low and all that germinated in 1996 were eradicated.

The experimental plants were not watered again by hand, nor were pesticides used to reduce herbivore damage. When the first experimental plants flowered in early August, we began recording the flowering status of each plant at regular intervals (weekly for the BS population, and less frequently at the other three sites). Several times per week we noted which pollinator species were present at each site. Pollen fertility was quantified for 20 wild and 20 hybrid plants, using the methods described above and plants from two of the four sites. We also counted the number of seeds per fruit from 67 wild and hybrid fruits, each from a different plant at the BS population. We did not attempt to sample total flower or fruit production per plant because of the prolonged period over which plants senesced and shed their capsules (September-November).

In 1997, 1998, and 1999, we rototilled each population in late May or early June to encourage seedling recruitment and reduce the abundance of other plant species. Wild radish seedlings emerged soon after tilling and dominated the vegetation at each site. During the growing season, large weeds were removed by hand, but many individuals of other species grew intermixed with the radishes. Two of the populations, GM and PP, had small plants in 1996 and poor recruitment in 1997 (Table 2). In 1998, grasshoppers destroyed nearly every seedling that emerged at these two sites, but we rescued 164 seedlings at GM and 58 seedlings at PP by moving them to pots at another site. The GM plants were replanted prior to flowering, whereas the PP plants began flowering at an isolated location $\sim 0.5 \mathrm{~km}$ from their original site and were replanted in September. In September, manure was added to GM and PP to improve soil fertility. This resulted in a dramatic improvement in 1999, when survivorship of wild radish seedlings at these two sites was high and most plants were large (1.0-1.5 m tall).

Here we report flower color frequencies in 1998 and 1999, and estimates of population sizes for each year. In 1998, flower color frequencies were determined by counting all plants in 56 haphazardly positioned quadrats (each $625 \mathrm{~cm}^{2}$ ) at BS and GM; for the other two sites, where plants were temporarily removed to protect them from herbivores, we recorded flower color for every plant. In 1999, color frequencies were determined for 35 quadrats (each $0.25 \mathrm{~m}^{2}$ ) and two $5-\mathrm{m}$ linear transects at $\mathrm{BS}$ and $\mathrm{RR}$, and by counting all plants in haphazardly chosen patches at GM and PP, where the populations were much smaller (see Table 2 for sample sizes). Individuals with pale pink flowers were grouped with white-flowered plants, while those with bronze flowers were grouped with yellow. These plants will be referred to as "white" or "yellow" hereafter (in $1999,<2 \%$ of the plants had pink or bronze petals). Estimates of population size were based on direct counts when $<400$ plants were present or by subsampling when the population was larger. For the latter, we determined the average number of plants in 20-56 quadrats per site (quadrat size was $0.25 \mathrm{~m}^{2}$ or $1.0 \mathrm{~m}^{2}$, depending on plant densities) and multiplied this value by the total area covered by wild radish.

In 1996, we collected a sample of seeds from wild experimental plants to check for introgression of cropspecific markers. A total of 96 progeny were screened for GPI, PGM, and flower color alleles (one offspring from each of 54 haphazardly selected plants at BS and 42 plants at RR). This rather small sample was not intended for characterizing allele frequencies, but rather as a means of confirming that $F_{1}$ hybrids were able to backcross with wild plants.

\section{RESUlts}

\section{Potted plant experiment}

Hybrid plants grew well but remained in the rosette stage longer than wild plants. The average time from germination to flowering was $44 \pm 1 \mathrm{~d}$ for wild plants vs. $60 \pm 1 \mathrm{~d}$ for hybrids (mean $\pm 1 \mathrm{SE}, N=39$ and 24 individuals, respectively; $<0.001, t$ test). This delay was also manifest in the fact that $15 \%$ of the hybrids never bolted to flower, as compared to $2 \%$ of the wild plants $(P<0.05, G$ test $)$. Aphids appeared on the potted plants $\sim 2 \mathrm{wk}$ after flowering began and were sprayed at regular intervals with malathion. None of the wild plants suffered major aphid damage, but $18 \%$ of the hybrids that flowered were heavily infested, perhaps because they flowered later and/or were more susceptible to aphids. Plants that sustained heavy aphid damage or never bolted were excluded from comparisons of flower, fruit, and seed number below. Syrphid flies, halictid bees, and bumble bees were the most common pollinators, making $\sim 80 \%$ of the observed visits, and each flower appeared to receive many visits per day (Lee and Snow 1998). All of the wild plants had yellow flowers, while the $F_{1}$ hybrids were white or pale pink, as expected for progeny from wild plants crossed with cultivated plants that were homozygous for the dominant white petal-color allele.

In hybrids, on average $63 \%$ of pollen was viable, as compared to $92 \%$ of pollen in wild plants (Fig. 1). Pollen viability was quite variable, however, and three hybrid plants had $>79 \%$ pollen viability, while two wild plants had $<67 \%$ viable pollen. The number of ovules per flower was similar in wild vs. hybrid plants, averaging 7.0 ovules in both groups $(N=39$ and 28 plants, respectively), but hybrids produced only half as many seeds per fruit as wild plants (Fig. 2). This had a major effect on the number of seeds per plant, which was also $50 \%$ lower in hybrids. Hybrids produced $\sim 30 \%$ more flowers than wild plants, but the number of fruits per plant did not differ significantly (Fig. 2). Hybrid plants senesced by midAugust, well before the end of the growing season and during the time when 


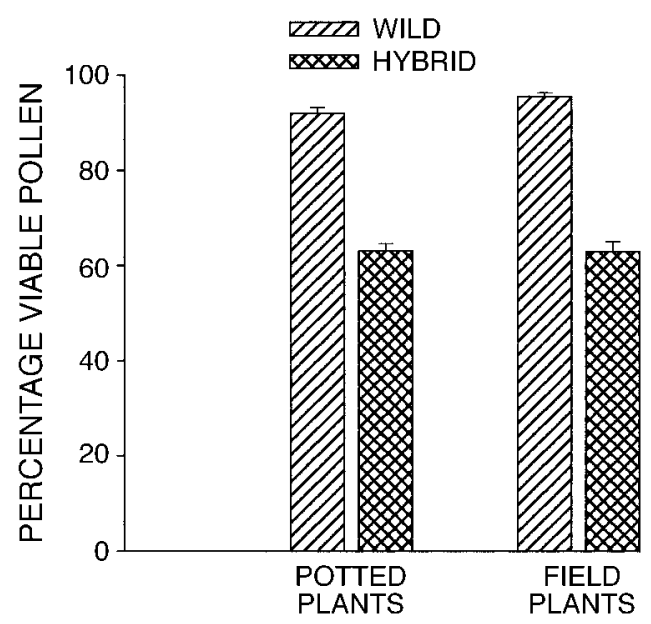

FIG. 1. Comparison of pollen fertility of wild vs. hybrid radish plants (Raphanus raphanistrum $\times R$. sativus) in the potted-plant experiment $(N=40$ plants per cross type; wild plants derived from a Michigan population) and the field experiment $(N=20$ plants per cross type; wild plants derived from a Maine population). All plants were grown outdoors. Data are means and $1 \mathrm{SE}$. In each experiment, differences between wild and hybrid plants were significant at $P<0.0001$ ( $t$ tests).

pollinators were still abundant. Diminishing numbers of plants in flower and low pollen fertility may have limited the availability of viable pollen toward the end of the hybrids' blooming period, but pollinator visits continued unabated.

\section{Experimental field populations}

Fitness of $\mathrm{F}_{1}$ hybrids.-Survivorship was very high in the field populations (Table 3), despite the fact that some plants sustained heavy damage due to grasshoppers, flea beetles, aphids, and occasional larvae of Pieris rapae. Plants that were severely affected by herbivores continued to produce new leaves, and most eventually recovered. Plants began to flower $\sim 5-12$ August
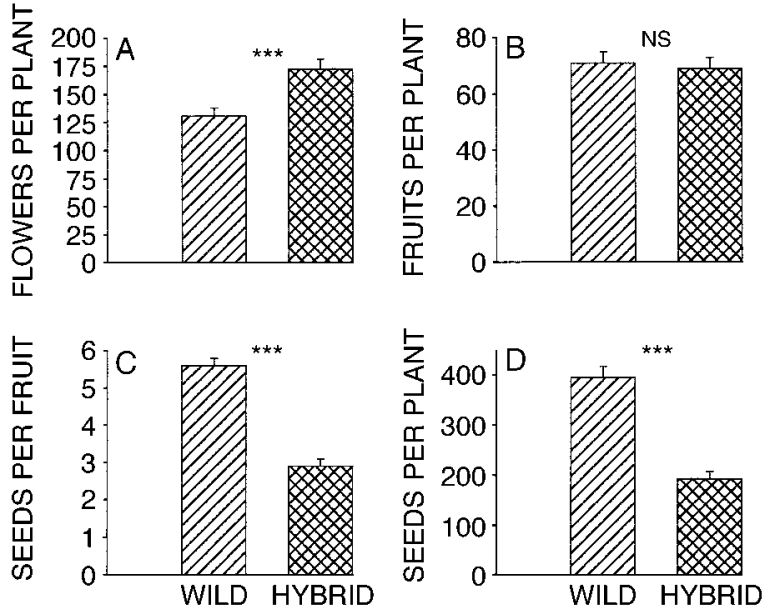

FIG. 2. Comparisons of reproductive success between wild and $F_{1}$ hybrid plants that flowered in the pot experiment. Means and 1 SE are shown; $N=38$ for wild plants and 27 for hybrids. Significance of differences between pairs of means is indicated by $* * *(P<0.001)$ or NS (not significant), based on $t$ tests.

and many continued flowering through November, stopping only after repeated hard frosts finally killed them. Plants that delayed flowering until October produced few or no fruits. Because cabbage butterflies (Pieris rapae) are known to prefer yellow-flowered $R$. raphanistrum over white-flowered plants (Kay 1976), we noted which pollinators were present. Pollinator composition in the four populations shifted during the 1996 flowering period. Syrphid flies and halictid bees were the only pollinators seen from early August until 17 August, when bumble bees were first observed: bumble bees gradually became more common. In early September we occasionally observed cabbage butterflies and honey bees, but the great majority of flower visitors continued to be syrphids, halictids, and bumble bees (A. Snow, unpublished data). Similar pollinator

TABLE 3. Survival, phenology, and fruiting status of Raphamus plants in the experimental populations in Michigan in the first year of the study (1996).

\begin{tabular}{|c|c|c|c|c|c|c|c|c|}
\hline \multirow[b]{3}{*}{ Status } & \multicolumn{8}{|c|}{ Sites } \\
\hline & \multicolumn{2}{|r|}{ BS } & \multicolumn{2}{|c|}{ RR } & \multicolumn{2}{|c|}{ GM } & \multicolumn{2}{|r|}{ PP } \\
\hline & Wild & Hybrid & Wild & Hybrid & Wild & Hybrid & Wild & Hybrid \\
\hline Dead & 3 & 1 & 1 & 0 & 1 & 0 & 0 & 0 \\
\hline Percentage flowering & & & & & & & & \\
\hline 5 Aug 1996 & 14 & 0 & 18 & 0 & 23 & 0 & 23 & 0 \\
\hline 15 Aug 1996 & 83 & 34 & 85 & 14 & 79 & 16 & 63 & 12 \\
\hline 6 Sep 1996 & 90 & 75 & $75 \dagger$ & 69 & 95 & 64 & 98 & 29 \\
\hline $\begin{array}{l}\text { Total percentage flowered } \\
(9 \text { Nov 1996) }\end{array}$ & 97 & 87 & 99 & 89 & 99 & 78 & 100 & 74 \\
\hline $\begin{array}{l}\text { Total percentage with fruits } \\
\text { (9 Nov 1996) }\end{array}$ & 95 & 78 & 97 & 71 & 95 & 62 & 92 & 60 \\
\hline
\end{tabular}

Notes: The percentage of all initial plants in each category is shown $(N=100$ initially and $N=97-100$ after accounting for plants that died). Site abbreviations are defined in Table 2.

$\dagger$ Some of the wild plants finished flowering early at this site, so there were fewer in flower on 6 Septermber than on 15 August. 


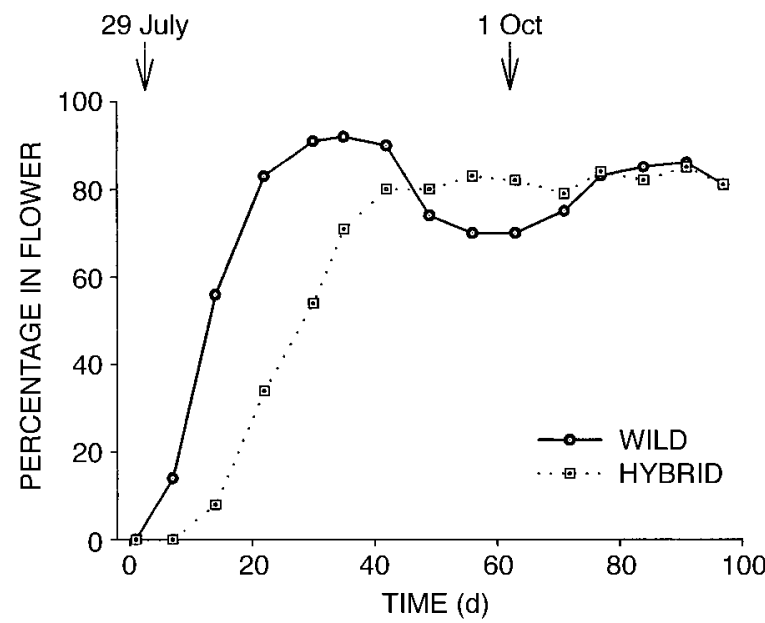

FIG. 3. Flowering phenology of wild and hybrid plants in the Biological Station population in 1996. Sample sizes were 97 wild plants and 99 hybrids.

taxa were observed in 1997-1999, but bumble bees were common throughout these flowering periods. Cabbage butterflies and honey bees were extremely uncommon in the experimental populations.

Wild plants reached peak flowering by late August, whereas hybrid plants flowered considerably later, especially at PP (Table 3, Fig. 3). Hybrids also produced fewer seeds per fruit than wild plants $(3.7 \pm 0.2$ vs. $4.9 \pm 1.3$ seeds/fruit, $N=67$ fruits; $P<0.01$ ), and fewer viable pollen grains (Fig. 1). At the RR and PP sites, respectively, 0.11 and 0.26 of surviving hybrids never flowered (Table 3). In contrast, all of the wild plants that survived $(>97 \%)$ also bolted and flowered. A large proportion of hybrids never produced fruits ( 0.22 at BS, 0.29 at RR, 0.38 at GM, and 0.40 at PP), while $92-97 \%$ of the wild plants produced fruits (Table $3)$.

Plants were smallest and slowest to flower at GM and PP, whereas they performed better at RR and best at BS (Tables 2 and 3 ). The poor growing conditions at GM and PP appeared to exaggerate differences between wild and hybrid plants in each population, with hybrid plants having lower relative reproductive success at GM and PP and greater success at BS and RR. In later years, populations at GM and PP remained much smaller than those at BS and RR (Table 2).

Persistence of crop-specific alleles.-The founding populations consisted of $50 \%$ white-flowered plants, all of which were heterozygous for crop-specific alleles. In 1996, some seeds of wild plants were sired by $F_{1}$ hybrids, based on their allozyme genotypes and flower color (recall that wild plants were homozygous recessive for yellow petals). For the 96 progeny examined, frequencies of diagnostic crop alleles were 0.7 GPI, 0.4 PGM, and 0.12 flower color, respectively. Only PGM was significantly different from the expected frequency of 0.125 , based on chi-square tests and assuming random mating in the founding population $(P<0.05$; data from BS and RR were pooled). This sample of progeny was likely too small to be representative of the next generation, however. The purpose of scoring these seeds was simply to document the occurrence of backcrossing between $F_{1}$ and wild plants.

Three years later, in 1999, white-flowered plants were still present in all four populations (Table 2). The highest frequencies of white-flowered plants were 0.22 at RR and 0.15 at BS. At GM and PP, where fewer hybrids flowered in the first year of the study, frequencies of white-flowered plants were only 0.08 and 0.10 , respectively. Similar frequencies were seen in 1998 (Table 2). At RR, the proportion of white-flowered plants increased significantly from 0.17 in 1998 to 0.22 in 1999 ( $G=8.19, P<0.005)$; changes at other sites were not statistically significant. Because flower color is a dominant marker, we do not know whether the increase at RR represents a change in allele frequencies and/or a change in the relative proportions of homo- and heterozygous plants. Another possible source of variation in crop allele frequencies was the soil seed pool, which was not examined.

\section{Discussion}

Our results show that after hybridization has occurred, crop genes are likely to persist in weedy populations of Raphanus raphanistrum, despite the fact that $F_{1}$ hybrids had lower fitness than wild plants. The main differences between wild and $F_{1}$ hybrid plants were seen in flowering times, pollen fertility, and seeds per fruit, as documented in both potted plants and the experimental populations. Crop genes caused the plants to produce thickened taproots and large rosettes, and some plants never flowered despite being healthy and vigorous. In the field populations, delayed development was most pronounced at GM and PP, the two sites where the plants and population sizes were smallest. The average pollen viability of hybrids was only 0.63 , as compared to $0.92-0.96$ for wild plants (Fig. 1). For potted plants, lifetime seed production of hybrids was $49 \%$ that of wild plants, reflecting the fact that hybrids had fewer seeds per fruit (field-grown hybrids produced $\sim 76 \%$ as many seeds per fruit as wild plants). Both pollen abortion and fewer seeds per fruit were likely due to heterozygosity for a reciprocal translocation in the $F_{1}$ hybrids (Panetsos and Baker 1967).

The combined effects of delayed flowering and reduced fecundity inhibited transmission of the white flower color allele to later generations. Nonetheless, crop genes persisted in all four populations. By 1998, the frequencies of white-flowered plants were 0.15 and 0.17 at BS and RR, while only half as many plants had white flowers at GM and PP. These frequencies changed little from 1998 to 1999 . We have not estimated allele frequencies for flower color because it is a dominant trait and it is unlikely to be selectively neutral. Polli- 
nators sometimes prefer yellow-flowered $R$. raphanistrum over white (e.g., Stanton et al. 1986, Lee and Snow 1998), and insect herbivores may also discriminate among flower color morphs (S. Strauss, unpublished data). Cabbage butterflies (Pieris rapae) and a syrphid (Eristalis arbustorum) in England strongly prefer yellow-flowered plants (Kay 1976, Stanton et al. 1986). The most common pollinators at our populations were syrphid flies (Syrphidae), halictid bees (Halictidae) and bumble bees (Bombus spp.). Several of these species show a slight preference for yellow-flowered plants when the frequency of whites is greater than $\sim 0.15$, but this preference disappears when whites are less common (Lee and Snow 1998; A. Snow and K. Flinn, unpublished data). Therefore, pollinator preferences for yellow-flowered plants could have reduced the fitness of $F_{1}$ hybrids somewhat, especially in 1996, when the frequency of whites was highest. Allozyme data should provide more accurate estimates of the frequencies of crop genes in each generation. In 1998, frequencies of crop-specific isozyme alleles ranged from $\sim 0.15$ to 0.20 in these populations, confirming that introgression has occurred (K. L. Uthus, A. A. Snow, and T. M. Culley, unpublished manuscript).

Regardless of the exact frequencies of crop-specific genetic markers, it is obvious that crop genes can persist in natural populations of $R$. raphanistrum for at least three generations and probably much longer. Previous investigators have mentioned the possibility that nonyellow petal morphs and smooth, unconstricted fruit capsules in populations of $R$. raphanistrum may be evidence for past hybridization with the crop (Kay 1976, 1978, Stanton et al. 1989, Kercher and Conner 1996, Lee and Snow 1998). Rare mutations could also introduce flower color polymorphisms into natural populations (e.g., Kay 1976, Waser and Price 1981). However, the white morph is sometimes common in $R$. raphanistrum, with no obvious fitness advantages, so we suspect that its frequency is often influenced by hybridization with $R$. sativus.

Flower color frequencies in natural populations suggest that hybridization between $R$. raphanistrum and $R$. sativus may have occurred repeatedly in both directions and to varying degrees throughout many temperate regions of the world. In California, feral populations of $R$. sativus often include individuals with yellow or bronze petals or $>40 \%$ aborted pollen, most likely due to past hybridization with $R$. raphanistrum (Panetsos and Baker 1967). Populations of $R$. raphanistrum in northern lower Michigan typically have 1$2 \%$ white, pink, or bronze-colored petal morphs, as well as rare individuals with low pollen fertility (Uthus and Snow, unpublished data). Kercher and Conner (1996) reported high frequencies of $49 \%$ white and $6 \%$ pink or bronze in Bay City, Michigan, and 36\% white-flowered plants in a population from Hamden, Connecticut, while a New York population was pure yellow. Populations of $R$. raphanistrum along beaches in Con- necticut and Maine are usually fixed for the yellow allele, whereas inland populations often have low frequencies of the white petal morph (A. A. Snow, personal observation).

In Europe, $R$. raphanistrum appears to be more variable than in the USA. Tutin et al. (1964) described several European subspecies of $R$. raphanistrum based on differences in flower color, flower size, fruit diameter, and leaf shape. These include a yellow-flowered subspecies that occurs along maritime coastlines, a pale pink-flowered subspecies found along Aegean shorelines, a white or reddish-flowered subspecies in cultivated fields of Spain, Portugal, and the Azores, and a subspecies known as raphanistrum with white or yellow flowers in cultivated fields throughout Europe. Kay (1976) reported that white morphs of $R$. raphanistrum often predominate in southern and eastern Britain, while the yellow-flowered plants predominate or form monomorphic populations in northern and western Britain. These studies also provide circumstantial evidence for past hybridization between cultivated or wild $R$. sativus and $R$. raphanistrum, although nonyellow morphs of $R$. raphanistrum could also evolve spontaneously.

Crop-wild hybridization has been implicated as a factor contributing to the weediness of feral $R$. sativus in California. Both the crop and $R$. raphanistrum were introduced into California by the 19th century, and Panetsos and Baker (1967) suggested that "introgression of raphanistrum characters appears to have been a major factor in converting the erstwhile crop plant, $R$. sativus, into a highly successful weed in California". Although there is no hard evidence for this claim, it seems likely that feral $R$. sativus could benefit from raphanistrum traits and/or heterosis. Remarkably, it now appears that wild $R$. sativus has hybridized extensively with California populations of $R$. raphanistrum, and "pure" $R$. raphanistrum populations have not been seen in recent years (N. Ellstrand, M. Stanton, S. Strauss, personal communication to A. A. Snow; A. A. Snow, personal observation).

It is also possible that evolutionary adaptations in $R$. raphanistrum have been facilitated by gene flow from cultivated $R$. sativus, although this has not been proven and requires further study. Fitness benefits of crop genes were seen by Klinger and Ellstrand (1994), who documented greater lifetime seed production in $F_{1}$ hybrids between cultivated and feral $R$. sativus in California. In their study, which involved intra- rather than interspecific crosses, wild and hybrid plants grown in outdoor pots did not differ in other components of fitness (i.e., germination success, flowering time, or paternal transmission of a crop-specific allele to the next generation). Langevin et al. (1990) also found evidence for higher fitness of $F_{1}$ hybrids between cultivated and weedy rice (both Oryza sativa). Heterosis and/or particular crop genes might also enhance the fitness of $R$. raphanistrum genotypes, despite the fact that some 
crop genes and/or chromosomal rearrangements are deleterious to wild plants (e.g., late flowering and heterozygosity for the reciprocal translocation). Beneficial crop genes can potentially introgress into wild populations when they are not linked to traits that would be deleterious to the weed. Worldwide, new varieties of weedy wild radish may be evolving frequently because cultivated plants can spawn feral populations, and both the crop and feral $R$. sativus are capable of hybridizing with $R$. raphanistrum.

Future adaptations in $R$. raphanistrum could be facilitated by the acquisition of transgenes from the crop. Biotechnology companies are currently concentrating on more profitable crops, but if transgenic methods are used to improve $R$. sativus, this species should be treated with caution. To avoid undesirable impacts of fitness-related crop genes that can spread to wild radish, we recommend that transgenic radishes with resistance to herbicides, diseases, herbivores, or stressful environmental conditions not be released if these resistance traits are beneficial to weedy populations (also see Klinger and Ellstrand 1994). Release from abiotic or biotic stresses that limit population growth could potentially allow $R$. raphanistrum and feral $R$. sativus to become even more abundant and widespread than they are today. Similar concerns apply to many other crops that also exchange genes with weedy relatives.

\section{ACKNOWLEDGMENTS}

We thank Norm Ellstrand, Subray Hegde, Jeff Conner, and Jim Teeri for helpful advice during the early stages of this research, and Tony Sutterly, Richard Spray, Robert Vande Kopple, Peter Curtis, Kevin Wehrly, Chris Vogel, Ted Lee, Sarah Berenson, Kathryn Flinn, and Jennifer Archibald for technical assistance. Jeff Conner generously provided seeds from Bay City, Michigan. The manuscript was improved by comments from Norm Ellstrand, Susan Mazer, Jeff Conner, Sharon Strauss, Maureen Stanton, Kathryn Flinn, Sarena Selbo, and Lawrence Spencer. This research was supported by funds from the University of Michigan Biological Station (UMBS), the Department of Plant Biology at Ohio State University (Biddeford Fund and Janice Carson Beatley Endowment), the College of Biological Sciences at Ohio State University, Sigma Xi, and an NSF REU Grant to UMBS.

\section{Literature Cited}

Alexander, M. P. 1969. Differential staining of aborted and nonaborted pollen. Stain Technology 44:117-122.

Arias, D. M., and L. H. Rieseberg. 1994. Gene flow between cultivated and wild sunflower. Theoretical and Applied Genetics 89:655-660.

Arriola, P. E., and N. C. Ellstrand. 1996. Crop-to-weed gene flow in the genus Sorghum (Poaceae): spontaneous interspecific hybridization between johnsongrass, Sorghum halapense, and crop sorghum, S. bicolor. American Journal of Botany 83:1153-1160.

Cheam, A. H., and G. R. Code. 1995. The biology of Australian weeds. 24. Raphanus raphanistrum L. Plant Protection Quarterly 10:2-13.

Chèvre, A. M., F. Eber, A. Baranger, and M. Renard. 1997. Gene flow from transgenic crops. Nature 389:924.

Colwell, R. K., E. A. Norse, D. Pimentel, F. E. Sharples, and D. Simberloff. 1985. Genetic engineering in agriculture. Science 229:111-112.

Conner, J. K., and S. Rush. 1996. Effects of flower size and number on pollinator visitation to wild radish, Raphanus raphanistrum. Oecologia 105:509-516.

Conner, J. K., D. Tjhio, S. H. Berlocher, and S. L. Rush. 1997. Inheritance and linkage relationships of nine isozyme loci in wild radish. The Journal of Heredity 88:60 62.

Ellstrand, N. C., and C. A. Hoffman. 1990. Hybridization as an avenue of escape for engineered genes. BioScience 40: 438-442.

Fischer, D. W., R. G. Harvey, M. J. Vangessel, T. L. Rabaey, and D. J. Bach. 1999. Response of oat (Avena sativa) varieties and wild radish (Raphanus raphanistrum) to thifensulfuron plus tribenuron. Weed Technology 13:144-150.

Holm, L. G., J. Doll, E. Holm, J. Pancho, and J. Herberger 1997. World weeds: natural histories and distributions. John Wiley and Sons, New York, New York, USA.

Jørgensen, R., and B. Andersen. 1994. Spontaneous hybridization between oilseed rape (Brassica napus) and weedy Brassica campestris: a risk of growing genetically modified oilseed rape. American Journal of Botany 81:1169-1175.

Kay, Q. O. N. 1976. Preferential pollination of yellow-flowered morphs of Raphanus raphanistrum by Pieris and Eristalis spp. Nature 261:230-232.

Kercher, S., and J. K. Conner. 1996. Patterns of genetic variability within and among populations of wild radish, $R a$ phanus raphanistrum (Brassicaceae). American Journal of Botany 83:1416-1421.

Kirkpatrick, K. J., and H. D. Wilson. 1988. Interspecific gene flow in Cucurbita: C. texana vs. C. pepo. American Journal of Botany 75:519-527.

Klinger, T., P. E. Arriola, and N. C. Ellstrand. 1992. Cropweed hybridization in radish (Raphanus sativus): effects of distance and population size. American Journal of Botany 79: $1431-1435$.

Klinger, T., D. R. Elam, and N. C. Ellstrand. 1991. Radish as a model system for the study of engineered gene escape rates via crop-weed mating. Conservation Biology 5:531535.

Klinger, T., and N. C. Ellstrand. 1994. Engineered genes in wild populations: fitness of weed-crop hybrids of Raphanus sativus. Ecological Applications 4:117-120.

Langevin, S. A., K. Clay, and J. Grace. 1990. The incidence and effects of hybridization between cultivated rice and its related weed rice (Oryza sativa L.). Evolution 44:10001008.

Lee, T. N., and A. A. Snow. 1998. Pollinator preferences and the persistence of crop genes in wild radish populations (Raphanus raphanistrum, Brassicaceae). American Journal of Botany 85:333-349.

Linder, C. R., I. Taha, G. J. Seiler, A. A. Snow, and L. H. Rieseberg. 1998. Long-term introgression of crop genes into wild sunflower populations. Theoretical and Applied Genetics 96:339-347.

National Research Council. 1989. Field testing genetically modified organisms. National Academy Press, Washington, D.C., USA.

Panetsos, C. A., and H. G. Baker. 1967. The origin of variation in "wild" Raphanus sativus (Cruciferae) in California. Genetica 38:243-274.

Raybould, A. F., and A. J. Gray. 1993. Genetically modified crops and hybridization with wild relatives: a UK perspective. Journal of Applied Ecology 30:199-219.

Rissler, J., and M. Mellon. 1996. The ecological risks of engineered crops. MIT Press, Cambridge, Massachusetts, USA.

Sampson, D. R. 1964. A one-locus self-incompatibility system in Raphanus raphanistrum. Canadian Journal of Genetics and Cytology 6:435-445.

Seiler, G. J. 1992. Utilization of wild sunflower species for 
the improvement of cultivated sunflower. Field Crops Research 30:195-230.

Snow, A. A., and P. Morán Palma. 1997. Commercial cultivation of transgenic plants: potential ecological risks. BioScience 47:86-97.

Snow, A. A., P. Morán Palma, L. H. Rieseberg, A. Wszelaki, and G. J. Seiler. 1998. Fecundity, phenology, and seed dormancy of $F_{1}$ wild-crop hybrids in sunflower (Helianthus annuus, Asteraceae). American Journal of Botany 85:794801.

Stanton, M. L. 1987. Reproductive biology of petal color variants in wild populations of Raphanus sativus: I. pollinator response to color morphs. American Journal of Botany 74:178-187.

Stanton, M. L., A. A. Snow, and S. N. Handel. 1986. Floral evolution: attractiveness to pollinators increases male fitness. Science 232:1625-1627.

Stanton, M. L., A. A. Snow, S. N. Handel, and J. Bereczky. 1989. The impact of flower color polymorphism on mating patterns in experimental populations of wild radish $(R a-$ phanus raphanistrum). Evolution 43:335-346.
Thomas, A., A. Moore, and H. Forcella. 1984. Drought feeding and the dispersal of weeds. Journal of the Australian Institute of Agricultural Science 50:103-107.

Tiedje, J. M., R. K. Colwell, Y. L. Grossman, R. E. Hodson, R. E. Lenski, R. N. Mack, and R. J. Regal. 1989. The planned introduction of genetically engineered organisms: ecological considerations and recommendations. Ecology 70:298-315.

Tutin, T. G., V. H. Heywood, N. A. Burges, D. H. Valentine, S. M. Walters, and D. A. Webb. 1964. Flora Europea. Cambridge University Press, UK.

Waser, N. M., and M. V. Price. 1981. Pollinator choice and stabilizing selection for flower color in Delphinium nelsonii. Evolution 35:376-390.

Whitton, J., D. E. Wolf, D. M. Arias, A. A. Snow, and L. H. Rieseberg. 1997. The persistence of cultivar alleles in wild populations of sunflowers five generations after hybridization. Theoretical and Applied Genetics 95:33-40.

Zemetra, R. S., J. Hansen, and C. A. Mallory-Smith. 1998. Potential for gene transfer between wheat (Triticum aestivum) and jointed goatgrass (Aegilops cylindrica). Weed Science 46:313-317. 